Transactions of the Anstralasian gossotiation for the gdvanremunt of saintent. MELBOURNE MEETING, 1890. 



\title{
INAUGURAI, ADDRESS
}

\author{
BY TIE PRESTDENT,
} BARON FERDINAND VON MUELLER, K.C.M.G., F.R.S., M.\& PH.D., \&C.

TuE first duty, derolving on me at this auspicious gathering, is to offer on behalf of the present Council of the Australasim Association, and not less from the depth of my own feelings tw all, assembled now, the very best of welcome. Patronised by the noble representative of her Majesty, graced frum exalted station also by the first lady of the land, generously countenanced by the Premier and the other members of the Ministry, extensively sustained by Melbourne citizenship, and prominently supported by the University, we enter on this second meeting of the Association witl every bright prospect. Indeed, our hopes are raised still mole by the success, achieved already in the eldest metropolis, since, through the genius and circumspect assiduity of the Sydney University Professor of Chemistry, the great liome morement became extended to these southern colonies. Called unexpectedly for this year to the position, which magnanimous impulses and unbounded generosity have assigned to me, I must so far speak of myself, as to assure you, that this mark of consideration will ever be valued by me beyond all expression; that I am conscious of having no claims to this high favour, unless it be by scientific seniority in these colonies, and that I will endeavour to fulfil those expectations, which are justly set on leader'ships in a grand festive concourse, such as we are now to celebrate. Before proceeding, it is incumbent on me to express my rejoicing at so large and so splendid an attendance at this meeting, which is even encouraged by the genial smiles of so many ladies ; and further, to offer my homage to the distinguisher office-bearers, to the kindful hosts and notably also to the accomplished Secretary, through whose united perseverance, graciousness and energy the hopeful aspect of the Melbourne cathering is mainly due. My eminent predecessor, the Goverument Astronomer of New South Wales, has in a powerful and learned address sketched the origin and objects of the Britisl 
Association for the Adrancement of Science, the tifty-eighth meeting of which was held in Newcastle during September of last year. Thus the bearings and aspirations of these science-musterings came anew before us here also from the great British home, whose lead and aims we are anxious to follow and to imitate even in these respects. Whoerer shared actively or even only passively in the engagements, for which this extensive union has been established, whether in Britain or on the continent of Furope ()$^{\circ}$ in Americil, must have realised how much vitutity is infuser into sciencework by these Associations through whole communities, how immensely inspiring the personal contuct with learlers in protressive thought is to indivirlual workers of all ranks and in all hirections; how plans are formed and problems submitted, otherwise likely unattenrled to or left indefinitely postponed, and how powerful and trusty an intluence by this widely spreasling and annually refresher organisation can be pxercised on the public mind, to speerl progress, particularly of utilitainn tendency, in ir telling and in an impressive manner. Indeerl, with the iniuguration of this Association commenced in new era for science in these dominions of the British Crown. It is to us a nowenent of historic significance of its own. It fills to the share of the stenter gatlerings, from which ours is an offspring, to veriew the alvince of science throughout its various branches in the oller seats of learning; I will therefore not attempt at the youthful stage of the Association here, to lay before you any methodical aml conmected nceounts of more recent events on the walk of knowledge, even should I thereby not anticipate, what my homourerl colleagues maty wish to explain or recorl in the respective sections, orer which they preside. Indeed, in these distant locations it seems at present nore important, to clear away some scruples, which prevent recognition of our purpuses, or to rentler nore fully known the wide accessibility, aftorded for joining in these peronic gatherings. The destination of this institution is a for wirler one, than may be supposerl generally by our fellow colonists. The word "science" seems in British communities sften to be understood, to apply to reseatrches in the domain of nature exclusively. The acceptance of the word in this sense would exclude from our scrope much of the best iclat of whit we lesire to accomplisll, whereas really we here would wish to embrace in our range of discussions and operations, whatever was meant by the ancient word "scire" and hence "scientia." We would extend this meaning as far an ever the rays of knowledge can illuminate, as far as ever the power of thought can penetrite. Sucial science, for which at the Exhibition of 1880 a congress was held here, over which ou exudite honoriry Treasurer presided, can merge rearlily now into sections of this Association. Though we camot expect every member, perhnps according to 
some European standard, to be engaged actively in pursuits of rliscovery with a strict scientitic bearing, I feel sure to express the feelings of all, whom professional positions or amateur-inclination bring together on the path of knowledge, when I atfirm, that the Association joyously aud gratefully welcomes all who will cheer us in our aspirations, will listen to our cliscusions, and will support us by that moral influence, which every educa ted and thoughtful laymau can bring to benr. Ours is a kind of scientific feleration full of soul. Every one can help. The wide scope of the Association thus being reuclered patent, us well is the ease of access, it might next be isker by the uninitiaterl, what are the wore direct objects, what the mone inmerliate tendencies, what the final rlestinations of this organisation, spread now also to a distant corner of the globe like ours? As you might foretell, we accept on Australian soil this movement-struted by an illustrious sage of Edinburuh-in all its benrings, lopes and responsibilities, with perhaps this one preference, that, while we cndeavour to follow the cosmopolitan course, as arlopted in the northeru world, we would cherish some predilection for maintaining a command over the tields of indigenous work in these far southern legions, witlout any wish however of monopoly, but with that patriotic sense, beconning to us as residents in this particular portion of the British Empire. Irrespective of carrying on original resenrel, wortly of a country of juvenile freshness, it is our duty more especially, to iustil the thow of information from so manifold sources near us ill such it manner, that new growth for further developments may arise through that limpid couse in all possible dircetions. IVe should and could arouse inew also all those, who may slacken, by example and by new inspirations. You can carry n spirit of research into the family-homes; you will leave in many an hospitable louse, which opens its cloors in a year of choice to illustrious participators of these uneetings, many reminiscences not less pleasurable than profitable through life. I slall not speak here of the living among leaclers in progressive knowledge, of those who yet are shining forth at the Liritish Association also; but I would wish to pay a word of homage to the deal - to thuse, whom many of you have still met, and on whose busts at solemn moments we would wish, if even in thought only and passive pensiveness, to place also here a laurel wreath. Thus, among Britons, such names come before our' memory as those of $J$. Herschel, James Ross, Finaclay, McClure, Sabine, W. Hooker, Lindley, Brewster, Wheatstone, Murchison, Danwin, Speke, Carpenter, Lyell, Brodie, Gould, Livingstone, S'erlgwick, Berkeley, G. Bentham, Simpson, Ploctor and a host uf other luminaries, reminding us likewise of an ourly Melbourne University professor, who at a meeting of the British Association about the midclle of the century, wis une of its principal 
secretaries. To one meeting the greatest lustre was given by the presidency of H.R.H. the Prince Consort. As there is is brotherhond of all nationalities in science, it may be pardonable when from my own bit of career I allurle to some experiences of forty-four year's ago, while attending as an active member what. might be called the Genman Association for the Adrancement of Science. A fight of thought brings rividly before me again such illustrious personages as Schleiden, one of the earliest investigators of the living cellule; D'Alton, one of the fommlers of embryology; Langenbeck, the great and conserrative surgical operator and his long-renowned disciple, Esmarch. There were also the Scandinarians Oersterl, Forchammer and Steenstrup, the one the main liscoverer of electro-magnetism, the other eminent in northern geology, the thirl an early expounder of alternative generation. It is as if $I$ lear once more the roice also of Kunze, the pteridologist; of Rammelsberg, a leading expert in analytic chemistry; of Writz, the horticultural monographer of the Ericea; of Volger, onc of the great authorities on voleanoes; of Krauss, the zoologic Caftiritian explorer; of Sonder, one of the anthors of the Cape-fora, and of Schacht, Roeper and Muenter, the eminent morpholugists and physiologists; some of gay communicativeness, others of calmer reservedness-all sprealing lnowledge in their own way, all happy and elated among their scientitic compeers, but also well aware, that their coming together then might be an only one in life! It is, as if $I$ were brought once more face to face with many a hero in science, nearly all now numbering with the dead; some of whom having attended the earliest meetings of the British Association, and thus by their appearance, then grey, among a multitude of junior investigators, linked together in a most fiscinating and exalting nimner onc generation with another in science. A felicitation coulcl then still be sent to Oken, the founder. You can all enter into the feelings of Virchow, who at the Berlin meeting of the German Association in 1886, while unfolding to the 3000 members once more the roll-book of 1828 . There were the mames of Humboldt, as President, of Berzelius, Ehrenberg, Woehler, Rurlolplii, Gauss, Weber, Johannes Mueller, Mitscherlich, Rose, Magnus, of Oersted also, and of many another scientitic immortality, each either a founder of a brunch of science or a real' of it into extensive vigour. Well may Virchow have exclaimed, that it was as if life became infused unce more into the dead signatures! No doubt many assembled now in this hall experiencer similar emotions, when attending meetings of the British Association, where they first of all, and perhaps never again, saw individually some of the coryphems, of whom they had ever so often heard and read, for whom they cherished an unlimited veneration, and whose memory becane thus dencer still. Some of the younger members, now heve 
present, may yet be spared to participate as veterans in the centenary celebrations of Sir David Brewster's founding the parent Association. To some extent and in a vivid manner we shall be able, to measure the onward course of science here by the periorlicity of these gatherings from year to year, from decade to lecarle. Much human faculty is always going to waste; let this Association in its popularity collect all stray forces, especially as here, on new grounds, the very novelty of research must stimulate to more ardent action and keener emulation. Crude empiricism gives way in all directions to scientific ruling; the multitude is awakening more and more to the importance of exact research; a tide has set in to carry knowledge with all accumulating rliscoveries into every possible application; hence the rapirl stricles of technic art and rumal industries, particularly in young, bustling communities. Yet commerce, as well as handicraft, often still undervalues science-work, while daily benefiting from it, though unseen, untecognised and unregarderl. But this Union can make its influence felt through deliberations and lirect recommendations, and perhaps most powerfully so, because its tendencies are so eminently practical and so unselfish. IIuch in that direction are indeerl our efforts, our aspirations, our hopes! We can at measured intervals in this Association connect resenches with an extensiveness and universality such as no other organisation can effect; yet we do not enter into rivalry with localised societies or institutions of learning; contrarily, on then we lean mainly for our mental sustenance.

The field of rescarch is ever widening, but the horizon gets clearer; the objects of research become more multitulinous, but the appliances for investigation are constantly enriched; volumes still more instructive supersede one auother; methods more facilitous are substituted for those of the past; incontestable observations are daily increasing, the elaboration of systems and records gets more completerl, and thus endless rlifficulties become removerl, which beset the path of former workers; by such means an ever-accumulating science-fortune is renderer available without individual freedom being impaired. Yet, while the network of knowledge expands and the widtl of the meshes decreases, the einpty interstices between the threads are proportionately augmented, though the fabric as a whole gains more firmmess. The greatest triumph of sciences consists in bringing them into the fullest contact, somewhat in an Aristotelean and Plinian-or speaking of our own epoch-in an Humboldtian spirit.

Discovery has its own rewards, and they are of the sublimest kind. When, as fal back as 1817 , the foumder of the British Association perceived the endless displays of his kaleidoscope, and behcld other before unthought-of marvels, he lifted in pious armiration his eyes to heaven, well recognising that each playful change in the picture or every other result from his optic apparatus 
was ruled as much by laws, universul and etermal, as the movements in the planetary world. In recent days the great anatomic Professor Hyrtl, after he saw his main work pass through eighteen editions and through many translations, discourses still, though blind, with youthful enthusiasm in classic Latin on the bearings of medicine. Sir Richard Owen, at the venerable age of an octogenarian, evinces still with freshness of mind a keen and joyful interest in comparative zoography, of which he is one of the main originators. A coëtanean of lis through the century, George Benthan, continued like Sir William Hooker after four scores of years still brisk in descriptive taxonomy for the plants of the work-engagements of severity, from which many a young worker even would shrink; the watching of fliscoreries in their speciality were to them a never-ceasing fountain of delight, it necessity for their intellectual existence. When Haydn, the predecessor of Mozart and Beethoven in composing symphonies, heard with great splendour the performance of his oratorio, the: "Creation" " one of his last works, he burst into teals at the passage, "It became light," and uttered in deepest emotion the words, "It is not from me, it is Divine inspiration." The? vilurations of the Eiffel-tower, the new structure, donbly as high its the Strassburg-spire, were attentively studied by Cherreul at an age of his more than that of a centenarian.

Grand and true discoveries, such as may more and more also, here be effected, are not, like meteors, flashing brillinitly but ephemerously across the sky; they are like the discerning of new star's of listing raliancy; and there is one mighty incitation, inasmuch as every achievement through progressire thought stamp: on it the name of the discoverer for all times, and as any single new achiesement mity have numbers of others in its sequence.

Let it be instanced, what since Galvani's time has been brought albout, until with lightning's speed electric messages ane now dashing in all directions through the world. It would be invidious to single out anyone comnected with this glorious progress for special praise, unless the Nestor of electrology, who, in co-operation with Gatuss fully fifty years ago issuerl the atlits of terrestrial magnetism, and still some years earlier made one of the first efforts to span electric wires over wide distances.

What long ago was sumnised by Faraday, and later on through calculations by Maxwell, has in the course of 1889 been proverl by Professon $H$. Hertz, of Karlsruhe, from real experiments, that the action of the electric current on the medium, through which it is carried, is the same as that produced by light; further, that the generation of botlo depends on the sane litws, and that the propulsion is effected at the sime velocity: The objectionable liypothesis of "action into ristance," which Teber ilready wished to swoid witl regard to gravitation, is orerthown by these new demonstrutions. 
In recent days many surptising and momentous discoreries were witnessed, but few ean be alluded to here. Among those, which have a practical and extensice bearing on daily requirements, some originated or were erolved through the genius of Edison, from whom, as one yet in the prime of life, still other inventions may be expected. Here I will refer only to that mode of luminosity, which may be regarded as much cosmic as telluric, and which now is brought within wide technical operation through particularly disintegrated cual glowing in absoluts vacuum-not without some previous suggestions and experiments by Sirlot and Swall.

So also is it startling, to hear the human roice now with telephonic celerity across a whole country, and hardly impaired in intensity. Through the combination of Cray's or Bell's telephone, with Edison's phomograph, messages can be fixerl-as you may be aware-in writing; while, by Hughes's microphone, the soum can be leard with extraor clinary distinctness.

Nations are now rivalling to possess the largest telescope, Melboume still carrying the palm for the southern hemisplere. Indeer, the great equatorial instrument here, with its four feet mimur, is surpassed only by that of Lord liosse, and equalled only by that of Paris. Astronomy became lately in wondrous details commected with astrophysics and astrophotography. Tho astrmomic department here, under our distinguished treasurer, Colonel Ellery's able administration, will extensively share also in the now comnencing international photographic chating of the sirlereal heavens. A gigantic refractor-telescope has been placerl in the clearest of air at one of the culminations, 4600 feet high, of the Californian coast-mange by a generous American minins opcritol :und anateur-astrononer, on whom fortune himl smilerl; and thus within the last year or two were revealed some empyrean marels, never beheld by mortal eye before; the nebular ring in Ly'a presented quite new and complicated features, and additional stars at or near the cyclic aggregations were discoreped by the astronomers of Mount Hamiltom, Professons Holden and Schaeberle. Here may be alluded to only one other result if these observers, attained under so exceptionally favourable circumstances within their celestial area, namely the elliptic nebul:n of Draco, with its fulgent hydrogen and nitrogen, is now shown to consist of coiled limgs. New planetoids may thus also from thence come within the range of vision, eight having been observed from elsewhere on the northern horen rluring 1888 ancl at the beginning of 1889 , thus bringing recorded numbers up to 283. The powel, which would be exercised by rery large teltscopes placed within the tropios at alpine elevations above the frequent course of clouds in air so much rarified, may be beyomel all present imagination. Nore "about the comets, as suploserl motern-swams, which hare entered the solur system," might 
perhaps be learnt from such positions. Spectroscopic obserrations by Huggins, Secchi, Vogel, D'Arrest, Finlay, Wiedemann, Schiparelli, Hasselberg and other philosophers lead to additional explanations in this respect.

What photography, an art discovered within the lifetime of many assembled here, in progressive scope may effect in future, is as yet mere conjecture. The producing already, but not the fixing as yet, of three of the principal colours within the present processes of this grorious art holds out some hope, that its faithful pictorial representations may become embellished yet by vividity of colouration emanating directly and thus merringly from coperative processes.

In a very different way other questions come before us. Whether in the organic world a supposed involuntary tendency of striving for higher rlevelopment and further melioration, whenever cincumstances ale favoumble, arises from uncontrolled impulses, so that nothing is left in a stationary distinctireness! Whether specitic values for clear diagnosis and systematic fixity have in the generality of cases been allotterl with adequate scope? Whether fertile hybridity is fal mole extensive, than we have litherto been led to suppose? Whether diversity in the physical conditions of nature can explain the vister development of signutic mammats and birls in the zoologic ages prior to the present? Whether forcerl accommoration or spontaneous adaptalility to altered eircumstances of existence can chinge gradually and even intinitely structural orgenisations and specific functions? Whether crowling out, howevel overwhelming, can extend to absolute amihilation in the free fields of nature, when undisturbed by human action, of whether this combat for space and search for nouristument is limited to mere repression? Whether among specific organisations the most powerful atways dominate to the extensive suppression of others more numerous? Whether "uganisms, which in the present creation-epoch became extinct by the hand of man, could possibly ever be restored, by jogressive growth, even aftel many lengthened periods and with every comrluciveness for resuscitation? IVhether our present means for research are adranced enough, to distinguish all innate peculiarities, with which distinct types in the olganic womld nue endowerl? Whether, if all this coukl be answered in the attimative, it would be suflicient to acesunt for the marvels of designs in organic individuality connected with vital processes, as revealed tu us from the simplest and minutest to the most complex and huge of living beings, all displaying perfection for their own ristinet purposes? Whether all our search for what is kuowable can ever learl to it worlly insight into the commencennent of all (rigination? Can we contribute from this Association, by original unbiassed research here in new countries, cowarts the answering these momentous questions? 
The wirler the climatic range, the greater the variability, so that for studying specific limitations of organic beings we here are placed in a more advantageous position, than those on whom the first elaboration of Faunas and Floras devolver in the homecotintries. When a phyto-pal:entulogist of tirst rank and life-long experience, such as Goeppert, roubted whether from that branch of knowledge much support conld as yet be obtained for the ascendance-doctrine, we are cantioned also so far, not to be overhasty in construing irleas and evolving theories with a view of universal applications. The opposite views on organic devclopment, defended respectively by two such eminent among earlier naturalists, as Cuvier and St. Hilaire, deserve profound consideration even now-a-rlays. We are anywhere and anyhow only at the thresholk of the temple of truth, and might thus jemain conscious of some of the last humble words of even a Nervton!

The dietum, supposerl to be reliable, "natura non facit saltus," is not universally applicable, not even in prlacontology, as demonstrited by the three well-marked stages of the Amelican horse. One of the sublimest of poets, not foreign to natural science, must lare been persuarlerl of a Golly opelation in nature, when he wrote-

"Wohl erkundbar is das Wirken,

Cnerforschlich bleibt die Kraft!"

The world would lose many of its charms to intellectual belolders, if observers sink too much into materialistic explanations and speculative reasomings. We all armire the sagrcity, displayed by vreat learlers in biolngy, to trace the building up of organic frames, ind to follow up observingly what is nunifest in respective cycles of vitality; but can we adopt with the evidence attained all the conclusions drawn therefrom? Let us deprecate extending theories beyond what is warranted by trustworthy observations; let us avoid hazarling opinions unsupported by facts; and above all let us rlistinguish between what is within hmman grasp and what must ever be concealed to the eyes of mortal beings!

The question has sometimes been raiser, what is a billion? but an answer of calculative correctness has but seldom been given, though in some thoughtlessness that enormity of numeric value may be often enough rashly applied. Thus we hear spoken of more than a billion tons of coal deposits in the Chinese province of Shansi ; and as the search through carboniferous areas has in this colony also just passer into a momentous stage, it would be well to remember, that in 1884 the actual output of coal came to a total of 409 million tons, two-fifths of this from Britain. From a naturalist's point of view, some fractional approach to the sulution of such ruestions might be arriver at perhaps, when the prodigiosity of nature's clisplays is consirlered in estimating, on the basis of some calculation, the total number of spore-caselets on the fronds of our hill-ferntree (Alsophila australis) at $\$ 00$ millions and that of 
the spores at 1000 millions ; when further it frirly can be assumed, that a large tree of our silver-wattle may produce as a tutal frum its copious masses of flower-headlets 2.5 millions of tiny flowers, 800 millions of stamens, and 8000 millions of the compound pollen-grains; when a red-gum encylaptus or a mann eucalyptus may exhibit the twenty-fifth part of al billion of stomatit in the whole of its foliage.

Let us turn to another subject. Choice areas, not necessirily very extensive, should be reserved in every great country for sont: maintenance of the original regetation, and therewith for thes preservation of animal life concomitant to peculiar plant.. There the endenic liches me greatest, there also the danger is more immincnt of these being swept out of existence, unless timely. measures are arlopted for the reservation of some sequestered spot, to which rural occupations should never be allowed to have any access with their disturbing influence on prineval harmonies. Such spots should be proclaimed for all times the people is inalienable property, and every inlabitant or visitor of the localiu should consicler himself the co-preserver of stch ireas, so as to inil in preventing accidental invasion or casual ignition or intentionil spoliation. Furthermore, to such places of sccurity should be transferred plants and animals of exceptional rality occurring near these seclusions. "Floral commons," thus established, wouli soon be anong the most attmetive fentures, not only for pleasur. excursionists, but also for travellers from abroal, and would aftiol future generations in rarious territuries smme idea of the wondroun natural beauty of regetable and inimal life in its once unique loveliness, pristine grace and unimpaired freedom. MFeasures like these once initiated would eam enduring gratitude, and would find initation in all countries, and particularly in those, where nature hias seattered its floral gifts most prodigiously orer the territorial expanse. Under intelligent supervision such places, through restricted concessions, might be nawle to yielu a greater income, than accruble throgh ordinary rumal occupation. "Who would not plead in this cause? as oul Field Naturalists' Club haw indeed so ferrently done already. More and more of rarities are: commencing to sucumb and to be mate unrestorable, and scarcely a spot seems safe on the face of the globe against the defacing hamil of man! To the Great Auk no longer any existence was allowerl on the remotest hiding-place of Tcelind, where the last foor pain sucemmbed, while courageously defending their nest! Will :uny remmant of the trike of the gigantic birds, lingering yet in the recesses of far southern latitudes, perhaps share the same fite? At this instance may be called into memory the tunching velsen by the greatest of German prets, relating how the chamois is driven by the relentless hunter to the utmost pinnacle of it. highlanrl-home, and then the Alp-spirit of the legend sallies forth with wrathful woice, "Pause! why do you hurt my herrl?" space. is left for all on earth! 
May also the forests bo pleaded for here in this assembly?

It should be a fixed plan in national eoonomy anywliere, $t_{1}$ maintain masses of forest-regetation near sources of rivers, and to establish some broarl arboreous bordering on strenns, where it does not extensively exist, as much calculated to reduce sweeping water-rolumes by soakage and mechanical retention. For this purpose, nut-trees, cork-oaks, basket-willows and other trees, prominently utilitarian, could be chosen. To whit reflections are you led, when a recent Hood of the Mississippi not only devastated the adjoining land in its course, but destroyed also, though protracted submersion, much of the existing riparinu woods; when property counting by millions of dollars is lost to a Californian railway company through one single flood directly traceable to destruction of forests; when two-thirds of the inhabitants of the populous Connemaugh Valley pelished by the dam-disaster ; when so recently and so terrifically quite a nilliou of people were drowned in the floods of the Yellow River, and another million of inhabitants dierl from starvation, epirlemicos and other miseries as the sequence of such vist calamity. Melely a small fiaction of the monetary losses involred would have sutficed to avert all this, if spent in well-regulated forestry. The corling of temperature in forests undel: orlinary circumstances means the reduction of much aqueous rapour to liquid humidity, and further the local 10 -preeipitation of gaseous moisture in aqueous density, with proportionate lessening of evaporation. Each of "our friends, the trees," is " factor, however" small, in this calculation.

If really it could be demonstrated, that forests exercise no influence whatever on atmospheric precipitation, nut even througl electricity, - an opinion lately advanced, but alout the correctness of which many do yet entertain the gravest coubt-then still romains to be considered whether through forests any country can obtain the fullest benetit from such aerial downpours as do occur. In North-westeru Anerici. the expression seems proverbial, "Rain follows the plough." The principle in both cases would be the same. Though moisture promutes spontaneous forest-growtl, we are fortunately not by its absence prevented, even in almost rainless zones, to clothic bare tracts of country with an arborescent mantle of verdure. Shoulrl some one in opulence desile to build up for hinself onf of the most listing of monuments, it would be by the hequest of an isoliterl primeval forest, ever untunchable, for the free enjuvment of the orderly portion of the public. The annal saborrlay," let us trust, will become universal as a legitimate holidiay, which will be looker forwarl to with delight, particularly by the juveniles, who, with a life of hope before then, can await lesults from pleasurable action and intelligent forethought. Celebrations like these are not without a lesson to the whole community. 
The increment to the wood-estate of Victoria would be now already 200,000 trees annually, if some slight tending followed the impulse of planting; even where trces naturally abound, adrlitions can be marle by choices from abroad, as anyhow forest culture should nowhere any longer be limited to maintenance anrl increase of species possessed by the region, but should in amplification be extender to whatever is hest and perhaps available as superior from other lands.

Here, where, so to say, we live under eucalyptus-trees, we are apt to undervalue their hygienic inportance, or to discard them altogether: Unfortunately also the multitude, notwithstanding many efforts made, is not yet sufficiently informed on sanitary measures; thus a large proportion of the general public does not even yet secm to recognise, that for plantations, such as were with special forethought laised since the last thirty years around this metropolis, pines were purposely chosen on account of the salubious effect of terebinthine antiseptic exhalations from these particular trees-a momentous consideration, where hundreds of thousands of inhabitants have alrearly crowded closely together, and where zymotic diseases are so frequent and often so severely raging, not to spenk of the sesthetic aspect in a zone of evergreen regetition, where main-masses of trees with deciduous foliage are cut of liarmony, while a six months' spring prevails against as much winter-time of colder regions; yet, for all that, what thoughtful people have regarled as the vegetative pricle of the enviruns of Melboume may be in danger of being sacrificed to capricions tastes and trunsient fashions. Tnterplautations of palns, banboos, and other contrasting plants were long since contemplated under the shelter of the pines, to relieve any inaginary or real monotony producerl by large masses of erniteruus trees, even where they were miscellineously grouped. Now to another topic.

Tf merely to a slight extent the trensures of nature hare been studierl anywhere, with what enthusiasm are visited then new regions in appreciative knowledge or detail converserlness. The chilh even on its school-walks, the recreation-seeking pedestrian, the travelling tourist, - after some previous glimpses into nature's areana-involuntarily sees more for rational and elevating enjoyment than the rest of the people, and that uncostly too, aml perhaps even with substantial profit.

In whatever direction our glances are cast on organic nature, we perceive marvels of clesign from the mouse-sized monkey to elephantine giants, living ox extinet; from the smallest lumming bird, half-a-dozen of them lardly weighing as much as an ordinary letter, to the now byegone Moa of giraffe-tallness; from the towering huge Athrotixis (or Sequoia) cypress-pine of Califomia to mosses of almost invisible winuteness, -all perfect in organisation for their own special purposes. But endless otler 
considenations press on the trained observer, only one to be touched on here. Can the time approximately be determined when the Diptroron stanped in gigantic paces our plains, an when the Thylacoleon roared in pursuit of uther matsupials, now exterminated?

One of the nost renurkable of objects within the whole range of biology is that of Symbiosis, the unexpectedly wide extent if which through the empire of plants having lately been demonstrated by Professol Beccari - the hospes not proring detrimental or often not even injurious to the host. Professol Frunk rery recently discovered that fungus-growth of quite peculiar kind at the extreme ends of the root fibres in oaks, beeches and trees allied to them, mediates the nutrition of them as necessity. Could all this be merely casual ? The Azolla, nourishing a mickirscopic alge, is an example near to us, just as in other but similin respects the native evergreen beech.

At the very time, when I left Europe, forty-two years ago, Count Suminski cliscovered, to the surprise of many of us, the antherilous and archegonous organs on the minute prothallus of ferns: but whether and how genetic relation exists between the primordial and the subsequently-developed sporangious orgaus on fern-fromis has never yet been traced ol explained; and this is all the more mysterious as regards fern-trees, such as abound here, when years intervene between the production of the prothallus and that of the spore-bearing caselets. See furthel the rast significance of what, at first thought, may appenr a nere trifling matter.

A small fly (Lestophones iceryae) was not long ago noticed as antagonistic to the coccid-insect Icerya purchasi, by the very observart $\mathbf{M}_{1}$. Eraser Crawforl, of Adelaide, though a closely allied $\mathrm{fly}$, Lastophonus monophlebi, infests mainly, if not exclusively, another coccid, the Monophlebus crawfordi, as shown by $\mathrm{Mr}$. $\mathrm{H}$. A. A. Skuse, so that even in introducing tle particular Diptere needed for subduing the Icerya very discrinuinative entomology must be brought to bear for coping with an evil of quite dreadful dimensions in Californian orehards, not to speak of what with the less powerful Coccinellides can be done. Thus the Agricultural Department of Washington found it necessary to send a professional entomologist purposely to Australia, in order that the Lestophones be established also on. the other side of the Pacific Ocean, to restore thus far "the balance of nature;" just at in another remarkable instance the vines of the United States are largely reared in Europe and elsewhere now for their immunity to the Phylloxera vastatrix, which from America invaded other. countries. Perhaps this parasite could likewise be subdued by other insects, such as would not attack the vines. If so, a question would be solved involving almost the whole interest of rupin prosperity in many wide regions. So then a new special field is opened anywhere for entomologic oloservations, with a prospect held out of high substantial reward. 
The deseribed species of living animals, according to a very recent calculation by Drs. Krauss and Lamprecht, largely from the works of Leunis and Brom, reach in number one quarter of a million! Of these me Manmals 2,300, Birels 11,200, Fishes 9,000 , Nollusees 2,300, Tnsects 167,000 (with 80,000 Beetles). But even in litest days these numbers became consiclemably augmenterl, thus that of the Micro-Lepidoptem from this part of the wortch by the strenuous resenrches of Meyrick.

The arlnissible species of describer living plants sumber not less than 200,000 now, as about 120,000 rasenlares, taken in a conservative sense, have been fuirly well rlefined, and as Prof. Saccarlo las given in his large recent work alone 27,000 cliagnuses uf fungacerous plants, so thit the total number of supposed species ithenrly to be rlealt with in rescriptive Biology cannot fall very much short of half a million species. Mitten enumerated and diagnosticised, twenty years ago, already 1750 sorts of gemuine inosses for South-America; the zealous and accomplished two Vice-Presirlents of the Biologic Seetion have, in spare houls, after their professional engagenents, recorclerl respectively 400 species of senweerls from the littoral regions off and nent Port Phillip, and 600 species of Polyzoa fiom the extratropie shores of Australia, the polyzoic faumi inerely of our great Bay here being richer than either that of the British shores or that of the Mediterrnean Seat. Over 1000 species of Australian tisles are contained in the Census, which we uwe to the Hon. Sir Willinm MicLeay, whom, to onr regret, illness obliged to relinquish in the Nelbourne meeting the position, assigned to him as a veteran of scientific prominence. Mr. Masters's Catalogue of Australian Bectles, lirgely from collections of the distinguished naturalist just numed, and commenced by his renownerl uncle, comprises T200 species; but since that was published consiclerable angmentations have taken place. Tnfleed, thousands nnd thousands of kinds of insects, particularly others than coleoptera, are fluttering and buzzing as yet unrecogniserl, unclassitierl and undescribed in Austratian air, entonologists throughout Furope and many elsewhere envying those here for the yet easy chances uf ubtaining novelties.

Let as an instance of rarity of species be arlduced the re-diswwery of Amansia manmillaris through some action of my own within the last few months on the rery isolated Abrolhos-rocks, rpposite Champion Bily, perhaps the only place of its existence, from whence a solitiry specimen of this oceanic alge, als one most exquisite for delicate beauty, structural tenderness and lovely coloration, whs brought by Pemm during Baudin's expedition of 1802, and rlescriber in 1809 by the Caen Professol Lamoruoux, thus tantalising phycologists all the while.

Irrespective of the seven descriptive rolumes, mainly by the incompanale Bentham, on the unirersal regetation of Australia, 
special works on the Hora of most of the Australian Golonics sre now provided, one for Queensland having been published by Ir. Bailey some time ago, and one for South Australia having heen just issued by Professon 'Tate, who also brought greologic and zorologie eonsiderations to bear on the vegetation there. Mr. C. Woore has furnisher the manuseript for the Flori of New Sonth Wales, with a prospect of early promulgation in a special volume. Sir Jas. Hooker's Floras of New Kealand and of Tasmiania, quite gems, emanated already many years ago as one of the results of Sir James Ross's antaletic expedition.

Though limiting these remalks to ahievements of latel times, I lo not wish to pass the nime of Robert Brown, because not cmly did he lay most extensively and firmly the basis for the system of Australian vegretation, but it was he also, whu took up) again norphology for plants, after the long interval since the migination of that branch-science by Wolfi, just when it was resumed for animals by Dollinger, *

Through gradually incereasing facilities for multiplication in iconography now, so far as plints are concerned, about one-tifth uf the known species have become repictured: Of illustrated momographies in vegetable natural history the most urgently lespuirer is one on Characene, an opus, which would bo of Incal interest in every part of the world, and particularly here, where this group of waterweeds abounrls.

lil one particnlar respect splentirl clances for facilitation or acceleration of scienee-work are not rarely lost at opportmo unments, namely, to require extensive authentic collections, the accumulation of whieh may have involved the saerifices of recreative ordinary pleasures through a whole life, the disbursement of $\therefore$ private fortune and the main-absorption of a brilliant mind in fixed research, whereby treasures may have been got together for material valuation simply unpriceable. Nowhere applies this more than in young colonies, where 110 opportunity should be missed, whenever sueh may sudclenly arise at long intervals, to complete the working material from abroad by what may be ntherwise ntterly mobtainable. The seeuring of the Linnean collections, by the forethought of a British servint to his country, is an instance in point.

The gifted Seeretary of the subsection for Musie in our gather-

A passage from the Aldrees is here omittel, in which the names were given of wientista, prominent in Australin during recent periols and mostly yet active iu resemreli: bat it lrovel impossible within the precinets of a general aiscourse, however propitions the moment, to allude to every one, who had attained celebrity in Australinn scientifio Jife. A hope is entertained, that at fnture meetings of the Assuciation full jnstice will be lone within the special scctions to the merits of varions and respective individual liscoverers, who constitute now alrealy quite a mititude of scientific worthies also in this part of the world. Two deviations from this course will be conntenancel by all witl ine lomage-to note especially the sumerb Decades, largely also palieontologic, issuen during the last 30 years by the veteran Protessor of the MLelbonme Uuiversity-and to bestow adequate recognition on the brillimi inamer in which the first Presilent of the A ustralian $A$ seocintion muintains the fame of oux elilest obeervatory. 
ing is anong those who endearored to rouse a spirit for beautifying our landscapes as well as our immediate surroundings. Biologisti, particularly, could add to the chams of vernal vegetation anywhere by transferring for naturnlisation from land to land, at allevents, the minutest of flowers, always innocent, such is here the neatest Candollcas; the snatching up and forwarding of a few grains of seeds, and their being merely scattered on arlequate soil in sinilar climatic regions, would suffice. Peculiarity in the constitution of the fruit enabled the Cucos-palm to transmigrate on its own accord from its home in the Westeru Hemisphere to the shores of the Eastcrn; it requires other means for the French-bean and the gourds to reach the East; for the last 300 yen's they were consumed as a frequent table-food of supposed eastern origin; but now only has it been shown, by archaeologic researches int: the Incas-times, that they belong as indigenous to the westeru world exclusively. This exemplities how objects of almost daily concerns can still aftord ureans for original inquiry for almost indetinite periods. The munificence of the learned President of the section for Literature and Fine Arts has fostered also this system of translocation, as shown last year by additional rery copious distribution of silmon-ora through Tasmanian streams.

Cissino for 1888 recolded 13,500 scientists as holding recognised positions in various countrics; but the respective numbers given seem adequate only for North America-thus far, nearly 5,000 names being giren. This, however, slows the extruordinary vividity displatyed there for original inventive work, and that very much of a practical kind.

Young Australia has placed hitherto aliearly through its science-societies about 130 volumes into the libraries of the world, and that mostly during the latter half of the century; a freshness perrades these litclary efforts, commensurate with the" ampler originality of sourcos in new countries. An enlightened jourmalistic press accords here no less than elsewhere its generous support to science. For the world as a wholc mental faculty is displinyed, never without a scientitic touch, in hundreds of thousands of journals, in uncountable periodicals, and in an endless number of spacious volumes. How is a riew to be maintained over this ever-increasing flood of literature, if evell for each of us in one or few directions only? At all events, in greater works a resumé of their salient contents should never be vanting, some summing up of the main-substance, some ablidged reference to novel elucidations. The idea of constructing an universal linguistic medium of communication, at tirst promulgated by Leibnitz in 1666, has occupied the minds of many of the learned ever since. Like numerieal tigures, chemical formulas and musical notes, such a language is to be readable by each nation in its own words, and the name Pasigraphy has been chosen for it. Volapük aflords steps towards accomplishing this, 
but does not solve the problem. Cun the principle of stenography be drawn into use for this purpose? Classic languages, grandly developerl more than 2,000 years ago, continue to give an antique firmness to international writing ; but, after all, Englan! hats given its linguange to alrendy one-fonth of the world, it languige of powerful conciseness and flexible expressibility, doubtless destined to become still more and more predominating in the course of time.

There is one publication which concerns Australia much, but is in its value here too scantily recognised-that of the Royal Colonial Institute, a union much brought about by the thoughtful activity of H.R.H. the Prince of Wales, and largely tendins, through essays and discussions of leading colonists, to unite the interests of the Pritish Colonies with those of the great homecountry for more solidifying the Empire.

Chronologie writings exist for political but not for scientitic events; a volume of the History of the British Assaciation would almost be equivalent to a connected record of discoveries effected since its founding, as foreign achievements were never lost sight of. A history of all universities from original local archives would carry authentic and comprehensive records of all sciences also into medieval remoteness, and yet could be held within trenchant briefness-local extra-academic working not likely being passed at the respective seats of universal knowledge. By the co-operation of specialists the prominent points of still earlier discoveries might be readily adduced quite into the dawn of civilisation.

A new principle for facilitating scientific pursuits deserves to be alluded to at this occasion on account of its wide applicability; ninmely: to afford special convenience for original research in distant countries, as thereby additional inducements are offered for particular studies far abroad. A commencement thus far was marle by the establishment of the biologic station at Naples. But to the Dutch belongs the credit of alopting ampler measuress in this direction, so far as to fit up local working rooms, and as to lessen the expenditure for a lengthened stay of naturalists in Java, one of the most attractive places, as you are awire, for whoever wishes to study nature in its tropical grandeur. Sereral leading scientists have availed themselves already of this inducement; and Ceylon-still nearer to Europe-so as to be witb sufficient advantage within reach during the long annual professional vacations, is now also resorted to. If Australia could follow this example, we would see oftener on our shores illustrious strangers, who might wish to spend a scientific furlough lather inmong widely different scenes in nature, and to roan anong a vast number of new objects, than to travel within much traversed anrl scientitically more exhausted areas ; and they might perhaps come accredited also is delegates to the Australian Association- 
slrould we mot prefer to invite purposely year ifter year leprestutatives fiom the older seats uf learning to gatherings here, as suggesterl at the last Merlical Congress. What a rich store of recent professiomal experiences would be sherl out before us, and lonw would we, while offering A ustalian huspitalities, endenvour' ta reciprocate from what could be olotamed from liere as scientifieally novel. But this principle has still another bearing. Tu Jivi, for instunce, pulnomary consumption seens never to hecome developer. More than tlat, a fortuightis stemmer-royage can bring, at a muderate cost, the plothisic invalirl fom England to Central America, for reaching, not ton far inland, any chosen revalions with light and pure air of easy respiration. The Inomitin-resions of extra and intra-tropical Australia, as well as mone of the elevated inland lowns. come likewise within this hycienic scope, especially for sufferers from a home sutticiently near.

Turning to geography, let here the question be asked, is concaning us most, low ean Australian explonation be arlvanced? 'Talent, enthusinsm and expelience are avalible at any noment for the purpose. Our first historic century liss passecl; will the

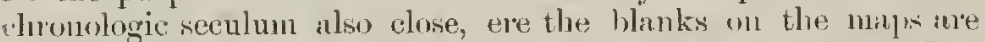
fillerl up? If so, it would be almost a reproich; and ming [ be allowel to repeat what, in a geographic uldress, was silid some few nonths reo: "The main work of Australian land-exploration devolved on nine truvellers only; now space seems inly left for rme more grentexplorer, to rink with the nine. Who will be the tenth to carry off this list of homors, $11^{\circ}$ will it be dividerl anumg sereral less ambitious competitors?" Well my the agerness be unterstood, to set the life on winning such a prize :

What a contrast, when we reflect that Pytheas reacherl the shetlind lstands, his "Thule," at the time of Alexander the (iveat; and yet, that it should require more than two thousand yours before socotia becume corefully exploted, and thereby alio its unique floral treasures mul other natural riches discloserl, this laving ouly been acomplisherl through nction of the British Association by Professor Batley Balfour within the list few vears, though cousses of navigation were close to that island since grey antiquity, its endemic aloe-plant having been finned allearly to the trading Phomicians, but remaining through all that time for science purposes uttelly unknown.

Manifold attempts have been makle, to map out the lealing fentures of the vegetation of varions countries on series of charts, inl to treat the stationary faun similarly; if this was done from arlequate material for every great region by uniterl efforts of those, locally best initiated, then might be constructerl comparatively complete zoo- and phyto-geographic athises for the whole globe, ind these would unfold at a glance the prominent types in a more impressive and instructive mannel than any sther. Co-speration is needert, to accomplish this, and more 
particularly so in Australiat. Our biologists might devise some feasible plan, to advance this subject from year to year at the Assuciation's meeting.

Capt. Engelhardt Jürgensen's singular enter'prise, now under progress, to sail in a lifeboat around the world, arose from ideas encouraged and matured in this metropolis. The buat is decked, dividerl into water-tight compartments, unsinkable, readily portible, never permanently upset, etsily set going in accirlent, and carries drinking water as hallast; it has stood a furious sea near the Bay of Biscay. We may thus expect the venturesume mariner with his companion, to arrive in due time, whereby a deed will be accomplisher as daring and nuique, as that of his frmous countryman, who lately crossed the south of Greenland.

Dr. Nansen is seemingly to receive inunificent support from it compatriot for an eftort to approach by land the North-Pole from Greenland ; this will likely prove the safest route, notwithstanding immense hindrances, because on that line will at all events be mostly a firm footing, and perhaps some game. If the best is made of a full aretic summer with sailing sleighs, it would be shown, to some extent at least, whether Greenland extends in terrestrial continuity still much further than $83^{\circ} \mathrm{N}$, while clances likely woukl acculue of wide riews onward from any ligh elevation. As one likely result, the mortherm limits of Greenland would at least be determined. At all events, it has now been shown, that arctic altitudes up to 10,000 feet are traversable.

Instances are too rare, considering the enormous private wealth necumulated in inmumerable cases, of calling explorers into the field, such as in our days brought Agassiz to the Amazon-river, Stanley, "the bravest of the brave" amon's greographers, to Central Africa, Nordenskiold along the whole cyast of North Asia.

But Australia is not without its Maecenates! Of this you will be reminded in the Wilson-Hall, in the Clarke and Wyselaskie Institutions, connected with the Melbourne University, while in the eldest city of Australia the main seat of science was cndowerl by Challis's princely munificence, and the Linnean Society is sustained lingely in a permanent home by the foremost of Australian zoologists. In the metropolis, west of us, the University owes souse of its principal ramifications to the Hughes and Elder bestowals. Ormond College and that of the Artisans here tell their own tale, wnereas a statue at the largest libiary in the Southem Hemisphere commemorates what well directed energy and untiring perseverance can individually bring ubout. But let us think also of the liberal support, accorded by suceessive enlightened Ministries and Parliaments, to early ind continued studies, without which high-mindedness many researches here could not have reached their present extent. 
Turning to antarctics so far as mere temperature is concerned, that to be encountered on the southernmost tablelind of ice, wouls probably not be lower than that endured by Nansen at elevations very lofty in Greenland, and the ascent of the ice-cliffs near Mount Erebus, froin convenient points of sloping shores, would likely alst) not be more perilous, than the scaling of some ice-crests of the Caucasus by members of the Alpine Club last year. The project of rcnewed south-polar exploration las heen diseussed in all it. bearings by the Antarctic Committee of the British Association, as well as here. We are not evel yet aware, to what circumstances the existence of the only deep gulf towards the South Pole is traceable, whether to volcunic influences, or to terrestrial contiguration, or to what other causes. Can the increasing pressure, exerciser by the constantly enlarging lieight of the contiguous immense southern ice-masses, induce perhaps volcanic disturbances through the enormous weight? The brcaking away of the crust or melting away from beneatl, where not on firm lind, seems quite out of proportion to the ever augmenting ponderousness, resulting from all aqueous precipitations erer there at once freezing, even at summer-time. What the effect of mere gravitation may finally be on this land of ice without any relieving open interjacent water-channels, concerns us even it such distance here as physicists and also as mere inhabitants vely much indeed; and it is worthy of full discussions in our meetings for years to come, particularly if data could be obtainerl as to the ratio of increase of the ice. The extensive and so patriotic Australian Natives' Association likewise adrocates renewed Antarctic disquisition; and surely these efforts will tend, to maintain also the glorious maritime supremacy of the British Nation, displayed formerly in the most distant of southern waters as much as elsewhere.

Now as to our own Alps. The circunspectness and energy of the Council, aided by public and private liberality, has providerl enjoyments, some with us not previously realised. Among these is a tour to our highlands. To most Australians and many of the Europeans here a visit to our Alps, through the steamlocomotive more and more coming within ready and easy reach, will have the charms of novelty. Particularly in early or in late hour's you will likely behold a kind of airy ocean, surrounding with gigantic waves, phantastic isles, formed by highland pinnacles visible above the sea of rapours, the sun's rays illuminating the calm or drifting clouds, resplendent in colorations of ever-changing and indescribable magnificence. You will there be in the purest of air of lightly respirable buoyancy. Whilst summer-heat parched already the lowlands, you will have vernal flower-fields of unique ever refreshed beauty; to wander over; close to this may lie never-melting snow. In this, what I would call the Australian Switzerland, pasture- and urchard-plots will soon be 
the homes of many new highlandes.s. You will be impressed with the solemnity and almost awe of stillness away from the haunts of man, feelings of human insignificance arising within scenes of nature so incomparably grand; there man is drawing nearer in his thoughts to the Divine Power ruling all.

Science nowhere can stand still! Linguistic science is not foreign to this Association. Thus, thell, time-hallowed cxpressions, though some of them may have come as a glossarian inheritage even from Pythagorean antiquity, and may have continued of dilily frequency, will have to give way to wordings in consonance with progressive discoverics. Organography, even in instances of worls, to which has been clung with tenacity since the Plinian ake, will have yet to undergo some changes for the sulke of greater ncuracy in retiniteness and morc cleamess in etymolngy. Commatation in more than one of current langunges could be brought lotter into accord with oscillations of thought. The hyphen might for fuller perspicuity be more drawn into use, and particularly so in organic chemistry, which fumishes, even at the latest of dites, words so unwieldy in reading, and so unpronounceable in length, for its complex-compositions, that one single word may be composed in unbroken array of as many is forty-tive letters, not unlike the extensiveness of constuction in some Oriential languages; while contraily, abbreviations to such an extent as "Salol" for" the new therapeutic chemical, "Salicylate of Phenol," "ppen" epually rleprecuble. Spcaking of ancient langunges, it night lassingly here be noted, from researches of Professol Sizyce, of i)ford, in wost recent days, that a brisk litern'y intercourse pxisted in cuneate lettering between all the counties from the Nile to the Euphrates during the fifteenth century before the Clristian era. This was shown by unearthing the ruins of the residence-town of Amenophis the Fourth. Contrast witl this the still existing stone-age of the Australian Nomades! IV here camnot hope, to idd much to what has been gathelerl allearly of the languages of the Australian aborigines for some further insiglt into the onward-march of the human laces and the history of their progress; but such chances, as may still exist, should not be lost for construeting further vocabuliries, ere the remmants of the last tribes arc passing away, or abandon their pristine languages, or forget their lore; what can still be securer will be all the morc valuable, because it will at best-be soseanty. hitudies of this kind will become more significant, since a Victarian divine, as $\rightarrow$ missionary in the New Hebrjales, traces the language there partly to scmitic origin. Indeed, linguistic reseavch assumes also liere now such magniturle, that it might be recommenclable to constitute hereafter a division for "science of linguages" in the section for liternture within this Association. The moment seems an apt one, to pay some homage at this spot itho to the benrers of the gospel, who, in their inostentatious yet 
severe and perilous task, have to in vast extent gachered, fixerI and systematiserl the longuages of savage tribes, doubtles. primarily in duties of holy eall, but thereby collaterally afforcling mens for comparntive linguistic studies and the philologio: subjects connected therewith. Indeer, the Bible is now translated intu more than 300 languages or their diversified dialects. What an iucalculable treasure is stored up by these biblic translations also in wordly aspects! Could the Assuciation possibly do some further good in insisting, that by the force of logic, slowuld be suppresserl any lefectiveness of thought in unch of coumonplace conversational and perhaps also literary pluraseology, ever without reflection reiterated. Some appeliations, vernacular or otherwise, are also here and there open to, improvenent yet; thus, to quote only one fimiliar instance, "Gumtrees," professionally speaking, would apply here to the: Wattle-Acacias, not to the Eucalypts. For the advantage of conversing in several languages, ind simultaneously to liwr: cliseluser the treasures of literature in originality, to learn two, three or even four, is at early childhood hardly more diflicult than one, if facilities in fantily-life enn be offered to the youthful retentive mind. Eren to orphan-children, provided for by the Stite, this benefit could he extended, inasmuch as sonte. juvenile inmates of orphannges might be rearlily trunsfered from the institution of one country to that of a neighbouring one. without any aditional expenditure for suppost, and with this philanthropic view, that nations, who unhaplily nourish mutual sentiments of asperity, would through the rising generntion by closer sucial contract draw nearer to each other also ns grent communities, would learn more to respect national character. would recognise nore individual worth of their adversaries. would gralually be disabused of lostile prejudices, and wouli abandon supposed "1* exaggerated notions of their neighbour's firultfulness or enmity. This prineiple might perhaps be extenderl to all classes, with flumesticities sure to arise out of it with all their happy influences.

It is most pleasing, to see assigned to the highly scientific art of music so distinct in positim at this gathering, the division, constituter for it, being moreover enhanced in importance through at renuwed composer being identified with it. At all perions: of liunm existence the soul found its sublimest expression in lamonious tones. Emblenistically the sicred Scripture seizes on this mode of expression, as conveying to the utmost the ideas of mental loftiness : By nearly a thousand symbolic vocal and instrumental sumbls were tixed from almost mythologic lemoteness down to the olympian festivals; and well might. it be wisher, that some records of those melorlies were left, enchunting as they were even at the dawn of mental culture, to be eleciphered or restored at this age. 'To jurlge from 
the poetry of ancient periods, the music must then alrealy have been pervaded by great depth and richness of feeling. A magnificent piece of music surpasses even so far the most splendid of poems, as its sounds are the eloquence of one universal languagc. Amoig great operatic composers is one only, witlı whom word and sound emanated from the same mind and soul, and it is he also who never spent the sublimest of music on inarlequate themres; it is he who, with Meyerbeer, in utnost impressiveness grave to his musical effusions historic vividity, it is he who, thus fir knew to profit from the incomparable Avon-bard. Sor long as human succptibilities exist for what is elevating, so long will master-pieces of music, of poetry and incleed also of pictorial and plastic art be imperishable treusures, may they even lave come to us from the time even of the Iliad. If we think of the names of the great masters, should then not also with some thankfulness be a remembrance for those, who drew men of high renius into their patl or sustained them thereon? What would hav been the fate of Beethoven in 1808, had it not been for the aid of the then Arch-Duke Rurlolpl, of Prince Lobkowitz and Count Kinski at that turbulent time? What would have become of Schiller at his protracted illness without the ammuity spontaneously, in the most delicate of terms, bestowed by the Danislı Crown-Prince anrl Count Schimmelpfenning, and that at a period when national and private resources were alike absorbed to a vast extent, because all Europe was in arms, not to speak of numerous other instances, when genius was in clanger to be extinguished by worldy narwowness. The sumy sky of Australia-seems to kindle a general love fur music, and has called fortl many a talent already, som: celebrating triumphs in the centres of European art, while a youth of this city carried off there among unmerous competitors the Mozart-fellowship. But distinctions for this our great land lave not only been earned in the glorious cause of music.

Photolithograplyy, if not altugether it dicl arise in Victoria, became universally adopted in the particular process, claborated here, and tirst explained before our Royal society by one of Liebig's disciples, who tuo early became alienated from this colony. There also were first enunciated, however briefly, the views of tho author of the Unseen Universe on the effects of rays, emanating from rarious substances; and these early studies were followed up by a long series of appertaining researches at the great Hom Ghselvatory of Kew. Bremman's torpedo is a Victorian achierement, recognised as highly important by the Fitish Govemment, and lias proved lucrative to the constructor.

It is abrut at humbel year's ago when Galvani led the know. lerlge of electricity into new courses for unforeboled rast influences through the technic world; when Goethe conceived the first am far-reaching iclens of orginic metamorphosis: when Sir Jannes Sinith establisherl the first society of just pretensiveness for is 
special science; when the secmd Jussicu constructed his natural system of plants, perfect for all points but one, unless in details; when the elrler Helschel erecter his great tolescope at Slough, the discuvery of the sixth and seventh satellites of Saturn heing anumg the earliest results obtained; when the elder Grertner foumderl crupolugy; when the Danish Professor Otto Mueller astablished in taxomomy the genus Bacillarid, he, even as a physician, but little foreseeing, what solicl basis he was gaining in une direction for the future extension of pathology; when Roxburgh settled in India, as the first to elucidate in a morlern sense the Hora of an extensive region by indepenrlent extrEuropean resenrches; When Lavoisier published his Trait' de Chimie as the enoliest main-pillar of the present system of chemistry, not long betore he met lis cruel fate; when, mirlst itlier contemporaneous exploits, it fell to the sliare of Vancourer to enst the first inrchor in St. George's Sound for vast extension of the British dominions in this continent.

Australin, although me of the latest of original aloodes of man. maly yet also be destined perhaps to be the field of some of mankimlis greatest achievements. The Biblic words, Mnttlateus : "Tt is grond fror us to be here: let us build erlifices," is signiticantly applicuble to advancing civilized settlement through these fortunate doninions.

We are to coter sonn un the last decennimu of this century: that secular epoch, which to all human foresight will remain the most expansive for discoveries in the world's history, because it would seem, that in most directions not equal opportunities can re-alise for' inventive foundation-research within the sane space of time. Shall we be in the prourl position, that other ages will sily, "The nineteentl century has dome its work for" science well?" And what can yet be accomplished towarls its relofe liere and elsewhere? There will be some summing-up then of the sain of louman thoughts so fitr. Can the gergraphic chat of our plinet be finished by that time? Can the telegraph-wires be comected throughout all countries? Can the outlines of the serlugic map of our globe be completed? Can the systematic records of the famas mol toras be mainly brought everywhere to a close? Cin an miversil meteoroluy be evolved? Can chemistry exliatust then already the display of elementary substances and of their principal coalescences? And ean all this be helped on lncally by this Association, if even only to a small extent?

When probatsly a lecarle hence this Union will inaugumally rossemble in our metropolis, porbaps to witness then utso mgain anesther industrial fair of nutions in commemoration of the linking together of two centuries, many whom we are gladdlened to see yet among us will have passed awaty, resting urder the sods; but thugh then you will see them no more, they-like arlier comtemporries of sme of us-like Sturt, Mitchell, M. Stutrt, 
Leichhardt, Gould, WV. Slarpe, M'Leay, Gumn, Milligan, sprent, Dary, Jukes, Haast, McKinlay, Clarke, Castleman, TenisonWoods, Scortechini will have left for future inspiration and due gratitude many science-bequests of enduring value, gained largely om Australian soil ; yet some loneliness of its own may perhaps. le felt through missing them, for which the contact witl a yuunger generation can perhaps not always fully compensate.

Individual life at best is but short; through "the advancement of science" it can be prolonged, ean be rendererl capable of much augmenterl achievement, can he made susceptible to multi. phed enjoyments and much increased nsefulness. We advance trowards a greater future; what would we wish man's destiny in life to be? Can unprosperity be banished through amplest inrustrial productiveness? Can contentions be abolisher by a universal recognition of rights? Can savagerlom early be made to cease? Can finally each liuman being be erlneated to higher and worthier ideals? Can atheisu be marle to vanish? Can knowledge witl its Baconian password bring its power to bear, to aceomplish these most transcendental of objects? Can as interpreters of answers to such cosmopolitan questions all bearers of science throughout the world unite in a mental brotherhool?

And now some few closing worrs. Though white coming together in this Assuciation we do not engage in political discussions, yet in me aspect we might venture, to diverge from the strict path, markerl ont for science-votalies-it is in this, to forster also through our bouds the "union of the empire," under" permanent British supremacy. This must be the ardent wish of every true subject of our gracious Sovereign. Thereto point the grandest tiaditions, prominence in history, world-wide national influence, immeasurable strength of the realm, irresistible patriotic sentiments ; thereto also leads us reneration for the great homeland, with its keen sense of justice, philanthropic clemency, practical tendencies and iudonitable energy. May the reflex lays of that national greatness fall cver mobscured on us also here! What are we, whether in science or in any other consideration, without Britain in all its prototypic bearings and glory? Take this away, sever us from this, then the best of impulses, the greater contirlence in our purposes, as well as mu main guirlance and security, wonld be lost! And where would be our gratitude? Pritain bestowed on us a whole continent, with reanic lumndaries, within salubrious zones, exempt from autochthonic complications, with resources uncountable-all is a free gift, ins an mencumbered patrinony. The solidity of a great empire will also be a gnarantee for the best-connected and most luminous of science-progress in all dominions, orer which its sceptre sways; it will ever signalise a power, by which knowlerge and enlightenmont and indeerl religious reverence, also, will be surried 
with the widest permanency through the world not only for the welfare of the greatest of nations, but also for the tranquillity and happiness of all mankind !

"What guides man in his high pursuit, Opens, illumes and cheers his way?

Discerns immortals from the brute,

God's image from the moulds of clay?

"Tis knowledge! and that to the soul

Is power, is liberty and peace;

And, while celestial ages roll,

The light of knoreledge shall increase !" 



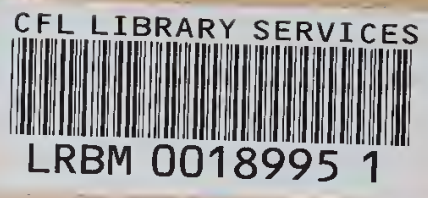

